Copyright ( 2019 University of Bucharest Printed in Romania. All rights reserved

ISSN print: $1224-5984$

ISSN online: $2248-3942$
Rom Biotechnol Lett. 2019; 24(6): 1111-1119

doi: $10.25083 / \mathrm{rbl} / 24.6 / 1111.1119$

Received for publication, September, 18, 2018

Accepted, October, 17, 2019

\title{
Review
}

\section{Antimicrobial compounds of the genus Bacillus: A review}

\author{
ROXANA-MĂDĂLINA STOICA ${ }^{1 *}$, MIȘU MOSCOVICI ${ }^{1}$, CATERINA TOMULESCU $^{1}$, \\ ANGELA CĂȘĂRICĂ $\breve{A}^{1}$, NARCISA BĂBEANU ${ }^{2}$, OVIDIU POPA ${ }^{2}$, HATICE AHU KAHRAMAN ${ }^{3}$
}

${ }^{1}$ National Institute for Chemical-Pharmaceutical Research and Development - ICCF, 112 Vitan Ave, District 3, Bucharest, Romania

${ }^{2}$ University of Agronomic Sciences and Veterinary Medicine of Bucharest, Faculty of Biotechnologies, 59 Mărăști Blvd, District 1, 011464, Bucharest, Romania

${ }^{3}$ Mehmet Akif Ersoy University, Faculty of Veterinary Medicine, Department of Food Igiene and Technology, 15030, Burdur, Turkey

\begin{abstract}
Antibiotics are low molecular-weight molecules produced as secondary metabolites, mainly by microorganisms that live in the soil. Microbial secondary metabolites have been a major source of clinically useful antibiotics. Members of the genus Bacillus are known to produce a wide arsenal of antimicrobial substances, including peptide and lipopeptide antibiotics. These peptides can be classified into two different groups based on whether they are ribosomally (bacteriocins) or nonribosomally (polymyxins and iturins) synthesized. The present paper provides a general overview of antimicrobial peptides derived from Bacillus species, including their structure and classification, as well as several extraction and purification methods used to obtain these bioactive compounds.
\end{abstract}

Keywords Antibiotics, Bacillus species, extraction, purification.

To cite this article: STOICA RM, MOSCOVICI M, TOMULESCU C, CĂȘĂRICĂ A, BĂBEANU N, POPA O, KAHRAMAN HA. Antimicrobial compounds of the genus Bacillus: A review. Rom Biotechnol Lett. 2019; 24(6): 1111-1119. DOI: 10.25083/rb1/24.6/1111.1119 


\section{Introduction}

Antimicrobial resistance gains more and more public attention as one of the biggest threats to prevention and treatment of an increasing number of infections. Thus, there is a great demand for a continuous supply of novel antibiotics to combat such diseases (J.J. HUG \& al [1]).

Microorganisms are the most potential source for production of natural therapeutic agents (A. BHARDWAJ $\&$ al [2]). The discovery and use of antibiotics, which have been produced by several microorganisms through secondary metabolic pathways has been one of the major scientific achievements in the earliest of $20^{\text {th }}$ century (M. RUKMINI \& al [3]).

The study of antibiotics began with the discovery of penicillin by A. Fleming and its subsequent introduction into therapy (S.L. DERDERIAN \& al [4]).

Antibiotics are chemotherapeutic agents that can be extracted from plants or obtained from microbial sources as secondary metabolites in the late logarithmic or early stationary phase of growth of batch cultures. Over 4000 antibiotics have been identified from different microorganisms, but only 50 have been commercially used to treat human, animal and plant diseases (R.A. SLEPECKY \& al [5]).

Secondary metabolites are synthesized by a wide variety of pathways, and both the specific genetic makeup of the producing strains and different environmental conditions can affect their activity. These molecules are primarily produced by microorganisms that live in soil. There are a few classes of microorganisms that can be used as sources for clinically useable antibiotics belonging to the genera Streptomyces, Cephalosporium, Penicillium, Micomonospora and Bacillus (S.A. MUHAMMAD \& al [6], A. BHARDWAJ \& al [2]).

Bacillus species are one of the largest sources of bioactive natural products, which exhibit a wide range of antibiotic activities and are produced as low molecular weight polypeptides, by ribosomal or non-ribosomal mechanisms. The amount of antibiotics produced by bacilli was approaching 167, being 66 derived from B. subtilis, 23 from $B$. brevis and the remaining peptide antibiotics are produced by other species of Bacillus genus (M. AWAIS \& al [7]).

In the scientific literature, already hundreds of different pathogenic strains have been described as test organisms in the direct activity-based screenings. The most frequent test organisms were Staphylococcus aureus, Micrococcus (Sarcina) lutea, Escherichia coli, Pseudomonas aeruginosa, Candida albicans and others (J. BERDY $\&$ al [8]).

According to their biosynthetic pathway, the first class of antibiotics comprises ribosomally synthesized peptides, including bacteriocins, whereas the second class comprises small microbial peptides synthesized enzymatically by non-ribosomal pathways (A.G. CHALASANI \& al [9], F. BARUZZI \& al [10]).
The ribosomal peptide antibiotics are produced during active cell multiplication, and non-ribosomal ones are produced during sporulation or after growth.

\section{Ribosomally sunthesized peptides}

Bacteriocins and bacteriocin-like inhibitory substances (BLIS)

Bacteriocins comprise a huge family of ribosomally synthesized peptides that usually show antimicrobial activity against strains that are closely-related to the producer strain (narrow-spectrum bioactivity) and sometimes against strains across genera (broad-spectrum bioactivity) (R.H. PEREZ \& al [11]).

Bacillus has been investigated for their ability to produce so called bacteriocin-like inhibitory substance BLIS. It has been reported that strains of B. thuringiensis, B. subtilis, B. stearothermophilus, B. licheniformis, B. megaterium and B. cereus produce BLIS (E.A. ABADA \& al [12]).

The classification of bacteriocins was previously established by KLAENHAMMER [13], NES \& al [14], and recently by ABRIOUEL \& al [15], which consist in three groups: class I includes antimicrobial peptides that undergo different kinds of post-translational modifications; class II presents nonmodified and linear peptides, and class III, which includes large proteins $(>30 \mathrm{kDa})$.

\section{Class I. Post-translationally modified peptides}

This class can be subdivided into four subclasses: Subclasses I.1-I.3 include peptides with typical modifications of lantibiotics (e.g. formation of lanthionine and $\beta$-methyl lanthionine residues), while subclass I.4 includes other unique modifications (ABRIOUEL \& al [15]).

\section{Subclass I.1. Single-peptide, elongated lantibiotics}

This group is represented by lantibiotics, which contain unusual amino acids, lanthionine and methyllanthionine (<5 kDa). Type A lantibiotics (2100-3500 Da; 21-38 amino acid residues) includes subtilin, a 32-aminoacid pentacyclic lantibiotic (3320 Da) produced by Bacillus subtilis.

Subtilin has the bactericidal effect on many Gram positive and certain Gram negative bacteria (A. GÁLVEZ \& al [16]). Subtilin production in B. subtilis is regulated in a growth-phase-dependent manner, starting in the midexponential growth phase and increasing to reach maximal level at the beginning of the stationary phase (P. KAUR \& al [17]). Structurally, it is similar to nisin from Lactococcus lactis (A.L. DEMAIN \& al [18]), epidermin and pep5 from Staphylococcus epidermidis, and to ericins from B. subtilis A1/3. Recently, Fuchs \& al [19] isolated entianin, which is a novel subtilin produced by $B$. subtilis subsp. spizizenii DSM 15029 with a strong antibacterial activity against S. aureus, E. faecalis, and other Gram-positive pathogens.

\section{Subclass I.2. Other single-peptide lantibiotics}

Subclass I.2 includes the type B globular lantibiotic mersacidin, and other lantibiotics, such as sublancin 168 and paenibacillin. 
Mersacidin (1824 Da) produced by Bacillus sp. strain HIL Y-85.54728, exhibits a more globular structure due to the formation of four intermolecular thioether bridges (type B). Mersacidin exerts its antibacterial activity by the inhibition of cell wall biosynthesis; this compound forms a complex with the peptidoglycan precursor lipid II as demonstrated for subtilin (J. PARISOT \& al [20]). Several works showed that this peptide successfully inhibited in vitro and in vivo the growth of Gram-positive bacteria including methicillin-resistant Staphylococcus aureus strains (MRSA) (D. KRUSZEWSKA \& al [21]).

Sublancin 168 (3877.78 Da), produced by B. subtilis 168 , contains a single lanthionine linkage and two unusual disulfide bridges; this compound exhibits bactericidal activity mainly against Gram-positive bacteria including important pathogens such as B. cereus, Streptococcus pyogenes and Staphylococcus aureus (J.Y.F. DUBOIS $\&$ al [22]).

Paenibacillin is a lantibiotic of 2983.5 Da produced by Paenibacillus (Bacillus) polymyxa OSY-DF, which also produces the peptide antibiotic polymyxin E1 (Z. HE \& al [23]). Due to their high affinity for the lipid moiety of lipopolysaccharide and disruptive effect on membrane integrity, polimixins are used against Gram-negative bacteria infections (D. LANDMAN \& al [24], F. BARUZZI \& al [10]) produced by Clostridium sporogenes, Listeria spp., S. aureus and Streptococcus agalactiae species.

A.A. ARIAS \& al [25] identified amylolysin, a putative type B-lantibiotic, that was isolated from B. amyloliquefaciens GA1 strain. Pure amylolysin was found to have an antibacterial activity toward Gram-positive bacteria, including methicillin resistant Staphylococcus aureus, and Listeria monocytogenes strains.

\section{Subclass I.3. Two-peptide lantibiotics}

Subclass I.3 includes the two-component lantibiotics, such as haloduracin and lichenicidin.

Haloduracin, produced by the alkaliphile isolate Bacillus halodurans $\mathrm{C}-125$, which provides bactericidal activity against a wide range of Gram-positive bacteria, including Listeria, Streptococcus, Enterococcus, Bacillus and Pediococcus species (A.L. McCLERREN \& al [26]).

Also, Bacillus licheniformis ATCC 14580 and Bacillus licheniformis DSM 13 produce lichenicidin, a "putative lantibiotic mersacidin precursor" (J. DISCHINGER \& al [27]). It exhibited antimicrobial activity against all Listeria monocytogenes strains tested, as well as methicillinresistant S. aureus (MRSA) and vancomycin-resistant enterococci strains (M. BEGLEY \& al [28]).

Subclass I.4. Other post-translationally modified peptides

Subclass I.4 includes the unique cyclic peptide subtilosin A, ribosomally synthesized by B. subtilis ATCC 6633 and other B. subtilis strains, as well as Bacillus amyloliquefaciens, with a strong bactericidal activity against L. monocytogenes and Gram-negative bacteria (C.E. SHELBURNE \& al [29]).

\section{Class II. Nonmodified peptides}

Class II of bacteriocins consists of heat-stable, membrane-active peptides without modified residues and can be subdivided into three subclasses.

Subclass II.1. - Pediocin-like bacteriocins

Pediocin-like bacteriocins, include coagulin, a proteasesensitive peptide produced by Bacillus coagulans I4 (C. LE MARREC \& al [30]), and proved bactericidal activity against pathogens like Leuconostoc, Pediococcus, Enterococcus and Listeria.

Subclass II.2. - Peptide- like thuricin

B. thuringiensis is also able to produce BLIS, such as tochicin $(10.5 \mathrm{kDa})$ and the large family of thuricins, (J.W. JIN \& al [31]) with a broad inhibitory spectrum, including L. monocytogenes, Salmonella enterica and Pseudomonas aeruginosa. Thuricin 17 (3160 Da) inhibits B. cereus strains, E. coli MM294, thuricin H (3139.51 Da) is active against a wide range of Gram-positive bacteria, such as Bacillus spp., Listeria spp. and Staphylococcus aureus. Bacillus cereus produces bacteriocins as cerein MXR1 (3137.93 Da), which shows a wide spectrum of inhibition mostly against Gram positive bacteria (S. SEBEI \& al [32]).

Subclass II.3. include other linear peptides.

Bacillus licheniformis 26L-10/3RA produces lichenin (1344 Da), a chromosomally encoded hydrophobic BLIS, with antibacterial effect against Streptococcus bovis and Eubacterium ruminantium (F. BARUZZI \& al [10]). Bacillus cereus produce cerein 7A (3940 Da), 7B (4893 Da), which exhibits a strong antibacterial activity against Gram positive bacteria. Thuricin 439 produced by B. thuringiensis B439 consists of two active peptides (A and B) with slightly different molecular masses (2919.9 and 2803.8 Da, respectively). Thuricin 439 shows a narrow spectrum of activity against $B$. cereus, $B$. thuringiensis strains and $L$. innocua, but not against Gram-negative bacteria (H. ABRIOUEL \& al [15]).

Recently, J. WANG \& al [33] identified the cerecidins, including cerecidin A1 and A7, a novel class of lantibiotics that are produced by Bacillus cereus. They exert antimicrobial activity against a broad spectrum of Gram-positive bacteria and exhibit high efficacy against some drug-resistant pathogens, implying potential applications as peptide antibiotics in food preservation or pharmaceuticals (L. ZHANG \& al [33]).

\section{Class III. Large proteins}

The A-group megacins include the inducible megacins A-216 produced by B. megaterium 216 and A-19213 produced by $B$. megaterium ATCC 19213. Bacillus cereus produces cereins, such as cerein $8 \mathrm{~A}$ produced by $B$. cereus $8 \mathrm{~A}$, which inhibits several pathogenic and food-spoilage microorganisms such as L. monocytogenes (D. BIZANI $\&$ al [34]). 


\section{Non-ribosomally biosynthesized peptides}

Non-ribosomally generated amphipathic lipopeptide antibiotics with condensed $\beta$-hydroxyl or $\beta$-amino fatty acids are widespread in B. subtilis (T. STEIN \& al [35]; E.A. ABADA \& al [36]). These are synthesized by large multienzyme systems that have a modular structure. Lipopeptide antibiotics identified so far have been divided into three main groups according to their structure: iturin group and macrolactones, like surfactin and fengycin groups T. STEIN \& al [35]. All these agents occur as families of closely related isoforms which differ in length and branching of the fatty acid side chains and in aminoacid substitutions in the peptide rings. These agents are natural compounds with a high potential for biotechnological and pharmaceutical applications (M. ALAJLANI $\&$ al [37]).

The iturin group is a large family of cyclic heptapeptides with a $\mathrm{C} 14-\mathrm{C} 17$ aliphatic $\beta$-amino fatty acid. The group includes iturin (variants $\mathrm{A}, \mathrm{C}, \mathrm{D}$ and $\mathrm{E}$ ), bacillomycin (D, F, L and Lc) and mycosubtilin, as well as other variants with names that reflect their bacterial source (e.g. mojavensin (C.R. HARWOOD \& al [38]). Iturin production is strongly associated with $B$. amyloliquefaciens and closely related species, such as B. velezensis. All members of the iturins group have strong antifungal activity against a number of important fungal pathogens (e.g. Rhizoctonia, Penicillium, Aspergillus, Fusarium and Pyricularia) (Y. TOURE \& al [39]) and, consequently, strains producing these compounds are being developed as potential biocontrol and plant growth promotion agents (C.R. HARWOOD \& al [40]).

Lipopeptides of the surfactin family (surfactin, lichenysins and pumilacidins) are produced by several B. subtilis, B. licheniformis, B. natto and B. pumilus strains and contain a cyclic heptapeptide that forms a lactone bridge with $B$ - hydroxy fatty acids, and show antibacterial (against S. aureus) and also, antifungal activities (M.H.M. ISA \& al [41]).
Q. GOAFU et al [42] reported the antifungal mechanism of action of a new member of the surfactin family, named WH1 fungin, produced by $B$. amyloliquefaciens WH1.

Among small peptides, bacilysin produced by B. subtilis is also included, which contains an N-terminal alanine residue and L-anticapsin; the release of L-anticapsin irreversibly inhibits glucosamine synthase, involved in the synthesis of nucleotides, aminoacids and coenzymes, and resulting in the lysis of microbial cells such as $S$. aureus and Candida albicans (M. ONGENA et al [43]). Some strains of B. subtilis also produce chlorotetaine, a chlorinated derivative of bacilysin with similar antibacterial activity (T.G. PHISTER \& al [44]).

Also, gramicidin $\mathrm{S}$, a small cyclic peptide, synthesized by Bacillus brevis, is an important and powerful antibiotic, effective against a variety of Gram-positive and Gram-negative bacteria (M. BERDITSCH \& al [45]; J.W. LIOU \& al [46]).

Tyrocidine, a cyclic decapeptide produced by B. brevis (M.A. MARQUES \& al [47], E.A. FELNAGLE $\&$ al [48]) is active against several important pathogens, including the Gram-positive bacterium Listeria monocytogenes, the pathogenic fungus Aspergillus fumigatus, the yeast Candida albicans, and the human malaria parasite Plasmodium falciparum (M. WENZEL \& al [49]).

The non-ribosomal dodecapeptide bacitracin (1486 Da), released by some $B$. licheniformis and B. subtilis strains (O.A. SICUIA \& al [50]), proved to be an inhibitor of cell wall biosynthesis of Gram positive bacteria (E.C. AZEVEDO, [51], A. AMIN \& al [52]). Bacitracin is a mixture of at least 5 polypeptides, and consists of 3 separate compounds, bacitracin A, B and C. Bacitracin A is the major constituent. It is active against many Gram positive organisms, such as Staphylococcus, Streptococcus, anaerobic cocci, Corynebacter and Clostridia, but not against most other Gram negative organisms (A.A.H.S. AL-JANABI \& al [53]) (see Figure 1).

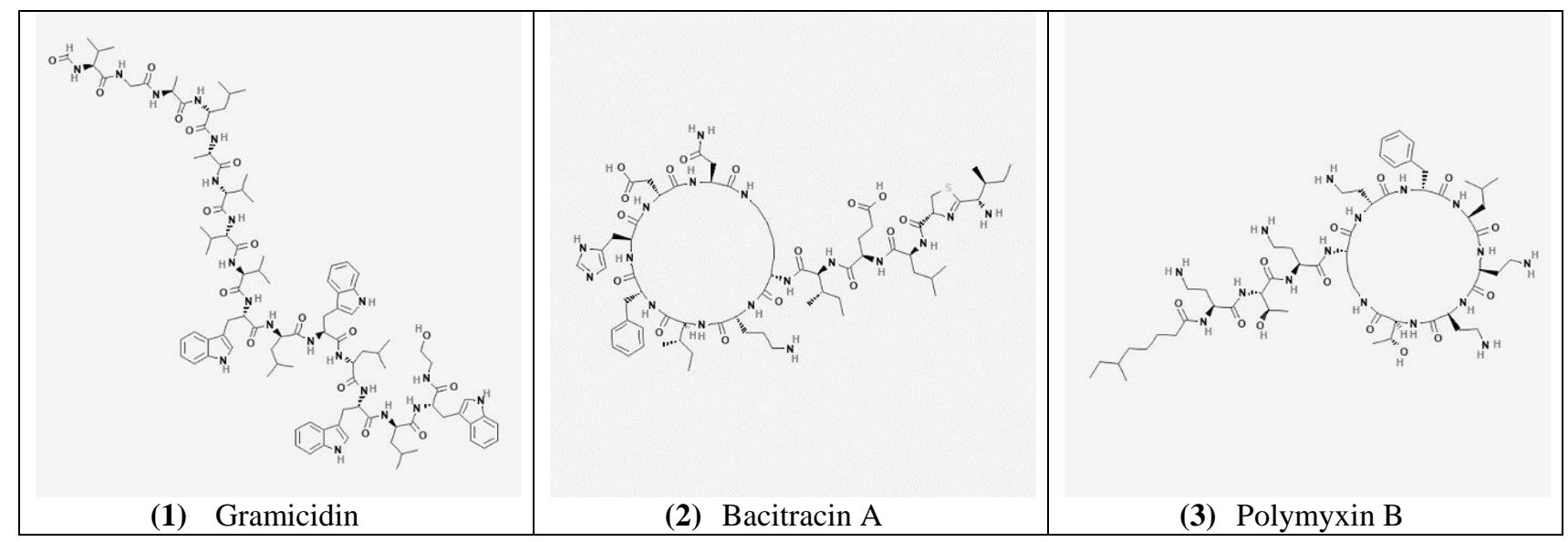

Figure 1. Chemical structure of some Bacillus antibiotics: 1) Gramicidin; 2) Bacitracin A; 3) Polymyxin B 


\section{Non-peptide-based antibiotics}

Bacillus strains also produce a variety of non-peptide antibiotics with different chemical structures.

I.V. PINCHUK et al [54] investigated 51 Bacillus strains isolated from different habitats, from which 47 have been identified as B. subtilis. Among them, there are 11 amicoumacins producers, a class of compounds responsible for antagonistic activity against $S$. aureus and Helicobacter pylori. Recently, a new member of the amicoumacin group, Hetiamacin B-D, was discovered from the fermentation broth of an endophytic bacterium, Bacillus subtilis PJS. It contained a special hexahydropyrimidine ring in the side chain of its chemical structure, and exhibited outstanding activity against methicillin-resistant Staphylococcus aureus (MRSA) (S. LIU \& al [55]). Other antibiotics are represented by macrolactins and their derivatives, succinyl or glycosylated macrolactin, containing three separate diene structure elements in a 24-membered lactone ring. Over 18 macrolactins from Bacillus spp. have been chemically described, which are considered to have antibacterial activity against $S$. aureus (M. ROMERO-TABAREZ \& al [56]). Difficidin and oxydifficidin, isolated from fermentation of B. subtilis ATCC 39320, represent a class of antibiotics characterized by highly unsaturated 22-membered macrolide phosphates and exhibit a good antibacterial activity against both aerobic and anaerobic organisms (L.B. ZIMMERMAN \& al [57]).

B. subtilis produces rhizocticins, phosphonate oligopeptide antibiotics, which exhibit antifungal and antibacterial activity (S.A. BORISOVA \& al [58]).
The increasing demands for new lead compounds in pharmaceutical and agrochemical industries have driven scientists to search for new bioactive natural products in extreme environments (L.S. SANTHI \& al [59]).

$\mathrm{LU}$ et al [60] isolated a novel macrolactin antibiotic from a culture broth of marine Bacillus $s p$, macrolactin $\mathrm{S}$, which exhibited antibacterial activity against $E$. coli and S. aureus. Novel thiopeptide antibiotics YM-266183 and YM266184 were found in the culture broth of Bacillus cereus QNO3223 which was isolated from the marine sponge Halichondria japonica. These antibiotics exhibited potent antibacterial activities against Staphylococci and Enterococci including multiple drug resistant strains whereas they were inactive against Gram-negative bacteria (K. NAGAI \& al [61]). A. AMIN et al [62]) investigated different soil samples from extreme conditions (saline soil) and screened for production of antibiotics against Micrococcus luteus and Staphylococcus aureus. The identified antibiotic was bacitracin produced by Bacillus strain GU057.

Z. NASFI et al [63] studied the potential for antimicrobial compounds production of different bacterial strains, isolated from rhizospheric soils obtained from Tunisian arid areas. Fungicides of the bacillomycin and fengycin group were identified. The study concluded that the isolated strain (Bacillus sp.) has a potential for the discovery of compounds with antibacterial and antifungal activities and highlights the high potential of the arid strains for the biosynthesis of specialized metabolites.

Table 1 summarizes the main Bacillus antibiotics.

Table 1. Some Bacillus antibiotics

\begin{tabular}{|c|c|c|c|c|}
\hline No. & $\begin{array}{l}\text { Producer } \\
\text { Organism }\end{array}$ & Antibiotics & Sensitive organisms & References \\
\hline 1. & Bacillus subtilis & $\begin{array}{c}\text { Subtilin, Ericin, Entianin, Subtilosin } \\
\text { A, Bacilysin, Mersacidin, Sublancin } \\
\text { 168, Bacitracin, Polymyxin, } \\
\text { Difficidin }\end{array}$ & $\begin{array}{c}\text { Gram positive bacteria, } \\
\text { certain Gram negative bacteria }\end{array}$ & $\begin{array}{c}\text { [16], [14], } \\
{[19],[27],} \\
{[41],[20],} \\
{[22],[47],[8]}\end{array}$ \\
\hline 2. & Bacillus brevis & Gramicidin S, Tyrocidine & $\begin{array}{c}\text { Gram positive bacteria, } \\
\text { certain Gram negative bacteria }\end{array}$ & $\begin{array}{l}45],[46] \\
{[47],[48]}\end{array}$ \\
\hline 3. & Bacillus cereus & Cerexin, Cerein & Gram positive bacteria & [69] \\
\hline 4. & $\begin{array}{c}\text { Bacillus } \\
\text { licheniformis }\end{array}$ & Lichenicidin, Bacitracin & Gram positive bacteria & [27], [48] \\
\hline 5. & $\begin{array}{c}\text { Bacillus } \\
\text { thuringiensis }\end{array}$ & Thuricin & Gram positive bacteria & {$[31]$} \\
\hline 6. & Bacillus coagulans & Coagulin & Gram positive bacteria & [29] \\
\hline 7. & Bacillus polymyxa & Paenibacillin, Polymyxin & $\begin{array}{c}\text { Gram positive bacteria, certain } \\
\text { Gram negative bacteria }\end{array}$ & [69] \\
\hline 8. & $\begin{array}{c}\text { Bacillus } \\
\text { halodurans }\end{array}$ & Haloduracin & Gram positive bacteria & {$[25]$} \\
\hline 9. & $\begin{array}{c}\text { Bacillus } \\
\text { amyloliquefaciens }\end{array}$ & $\begin{array}{c}\text { Bacillomycin, Mycobacillin, } \\
\text { Fungistatin }\end{array}$ & Molds and Yeast & [68] \\
\hline
\end{tabular}




\section{Several extraction and purification methods of bacteriocins produced by Bacilus spp.}

Bacteriocins are often extracted from culture broths by classical methods, including acidic precipitation $(\mathrm{HCl})$, recrystallization, and extraction by organic solvents. Unfortunately, impurities are co-extracted and the extraction must be completed by chromatographic procedures (F. PEYPOUX \& al [64]).

J.C. OSCARIZ et al [65] isolated and identified the bacteriocin cerein 7 produced by B. cereus strain. The bacteriocin was purified by a two-step procedure: first, ammonium sulfate precipitation of culture supernatants, and then, butanol extraction step, followed by the recovery of antibiotic from the organic phase. The compound was active against most Gram-positive, but not Gram-negative bacteria.

A series of new antibiotics have been isolated from well-known $B$. subtilis strains. These include bacilysocin, an anti-microbial phospholipid, that was isolated from B. subtilis 168 cells by extraction with $\mathrm{n}$-butanol and purification by Thin-layer chromatography (TLC). Bacilysocin demonstrated antimicrobial activity, especially against certain fungi (N. TAMEHIRO \& al [66]). Subtilin can be isolated from submerged culture fermentation broth by solvents extraction, (e.g. butanol, ethanol, n-hexane, ethyl acetate) and purified by counter-current distribution in a butanol-water system, ultrafiltration or nanofiltration processes (N.S. SHALIGRAM \& al [67]). QINGWEI G. et al [68] have purified bacillomycin D from Bacillus subtilis fmbJ using RP-HPLC method. Also, in the study of S. WU et al [69] antimicrobial peptides designated as Subpeptin JM4-A and Subpeptin JM4-B, produced by Bacillus subtilis JM4, were purified to homogeneity by ammonium sulfate precipitation, sequential SP-Sepharose Fast Flow, Sephadex G-25 and C18 reverse-phase chromatography. In another study, R.W. PHELA et al [70] have determined the purification of subtilomycin, a new lantibiotic from Bacillus subtilis strain MMA7 isolated from the marine sponge Haliclona simulans. The purification method involved an initial ammonium sulphate precipitation step (40\% saturation), followed by Reverse Phase High Performance Liquid Chromatography (RP-HPLC). P.K. DAS et al [71] extracted from the production medium polymyxin B (Bacillus polymyxa) and cerexin A (Bacillus cereus) and purified by comparing various methods, like adsorption through activated charcoal, acetone precipitation, dialysis, ion exchange and Sephadex column chromatography, with the best results on an Ion exchange column.

Therefore, the methods used to obtain antibiotics are relatively similar, including extraction with different organic solvents, and completed by chromatographic procedures, depending on each bioactive compound in part. Currently, of the several hundred naturally produced antibiotics that have been purified, only a few have been sufficiently non-toxic to be use in medical practice (Table 2).

Table 2. Different antibiotics clinically used

\begin{tabular}{|c|l|c|l|}
\hline No. & \multicolumn{1}{|c|}{ Producer Organism } & Antibiotics & \multicolumn{1}{|c|}{ Clinical uses } \\
\hline 1 & $\begin{array}{l}\text { Bacillus subtilis; } \\
\text { Bacillus licheniformis }\end{array}$ & bacitracin & $\begin{array}{l}\text { topically and orally in the form of creams, ointments, } \\
\text { and aerosol preparation, against staphylococci and } \\
\text { streptococci }\end{array}$ \\
\hline 2 & Bacillus brevis & $\begin{array}{l}\text { gramicidin } \\
\text { topical cream, ophthalmic solution, against bacterial } \\
\text { infections }\end{array}$ \\
\hline 3 & Bacillus polymyxa & polymyxin & $\begin{array}{l}\text { topical therapy against otitis caused by Pseudomonas } \\
\text { aeruginosa }\end{array}$ \\
\hline
\end{tabular}

\section{Conclusions and Perspectives}

Bacillus represent an important source of bioactive compounds as a result of numerous antimicrobial substances discovered for more than half a century. The identification of compounds with antimicrobial activity involves extraction from the fermentation broths, followed by purification and analysis methods in order to characterize their structure and chemical composition.

Nowadays, the discovery of new drugs from microbial sources represents a major challenge among the researches, because it is absolutely necessary to combat human pathogens that are resistant to antibiotics that have controlled them so far.

\section{Acknowledgments}

This research work was carried out with the support of National Institute for Chemical-Pharmaceutical Research \& Development, ICCF-Bucharest.

\section{Conflict of interest disclosure}

There are no known conflicts of interest in the publication of this article. The manuscript was read and approved by all authors. 


\section{References}

1. J.J. HUG, R. MÜLLER, C.D. BADER, M. REMŠKAR, K. CIRNSKI. Concepts and methods to access novel antibiotics from Actinomycetes. Antibiotics, 7:44, pp. 1-47 (2018).

2. A. BHARDWAJ, S. CHAMAN, S. VERMA. Production of antibacterial agent from fungi isolated from pharmaceutical soil sample by fermentation under optimized conditions. Asian Journal of Pharmaceutical and Clinical Research, 10:7, pp. 110-115 (2017).

3. M. RUKMINI, D. SAHOO, J. DALEI, R. RAY. Production, purification and characterization of bacitracin from Bacillus subtilis. The Pharma Innovation Journal, 3:12, pp. 77-82 (2015).

4. S.L. DERDERIAN. Alexander Fleming's miraculous discovery of penicillin. Rivier Academic Journal, 3:2, pp. 1-5 (2007).

5. R.A. SLEPECKY, H.E. HEMPHILL. The Genus Bacillus-Nonmedical. Prokaryotes, 4, pp. 530-562, (2006).

6. S.A. MUHAMMAD, S. AHMAD, A. HAMEED. Antibiotic production by thermophilic Bacillus Specie Sat-4. Pakistan Journal of Pharmaceutical Sciences, 22: 3, pp. 339-345 (2009).

7. M. AWAIS, A. PERVEZ, A. YAQUB, M.M. SHAH. Production of Antimicrobial Metabolites by Bacillus subtilis Immobilized in Polyacrylamide Gel. Pakistan J. Zool., 42:3, pp. 267-275 (2010).

8. J. BERDY. Bioactive Microbial Metabolites. The Journal of Antibiotics, 58:1, pp. 1-26, (2005).

9. A.G. CHALASANI, G. DHANARAJAN, S. NEMA, R. SEN, U. ROY. An Antimicrobial Metabolite from Bacillus sp.: Significant Activity Against Pathogenic Bacteria Including Multidrug-Resistant Clinical Strains. Frontiers in Microbiology, 6: 1335 (2015).

10. F. BARUZZI, L. QUINTIERI, M. MOREA, L. CAPUTO. Antimicrobial compounds produced by Bacillus spp. and applications in food. Science against microbial pathogens: communicating current research and technological advances, pp. 1102-1111 (2011).

11. R.H. PEREZ, M.T.M. PEREZ, F.B. ELEGADO. Bacteriocins from Lactic Acid Bacteria: A Review of Biosynthesis, Mode of Action, Fermentative Production, Uses, and Prospects. International Journal of Philippine Science and Technology, 08: 2, pp. 61-67 (2015).

12. E.A ABADA, H.H. EL-HENDAWY, M.E. OSMAN, M.A. HAFEZ. Antimicrobial activity of Bacillus circulans isolated from rhizosphere of Medicago sativa. Life Science Journal, 11:8, pp.711-719 (2014).

13. T.R. KLAENHAMMER. Genetics of bacteriocins produced by lactic acid bacteria. FEMS Microbiol Rev., 12:39-85 (1993).

14. I.F. NES, S.S. YOON, D. DIEP. Ribosomally synthesiszed antimicrobial peptides (bacteriocins) in lactic acid bacteria: a review. Food Science and Biotechnology, 16, pp. 675-690 (2007).

15. H. ABRIOUEL, C.M.A.P. FRANZ, N.B. BAKALI, A. GALVEZ. Diversity and applications of Bacillus bacteriocins. FEMS Microbioogy Reviews, 35, pp. 201-232, (2011)

16. A. GÁlVEZ, H. ABRIOUEL, R.L. LÓPEZ, N.B. OMAR. Bacteriocin-based strategies for food bio-preservation. International Journal of Food Microbiology, 120, pp. 51-70 (2007).

17. P. KAUR, P. SHARMA, F. AHMED, V. TEMBHURKAR. Optimization of Subtilin Production by Bacillus subitilis. Indo Global Journal of Pharmaceutical Sciences, 1: 4, pp. 362-368 (2011).

18. A.L. DEMAIN. Importance of microbial natural products and the need to revitalize their discovery. Journal of Industrial Microbiology and Biotechnology, 41, pp. 185-201 (2014).

19. S.W. FUCHS, T.W. JASKOLLA, S. BOCHMANN, P. KOTTER, T. WICHELHAUS, M. KARAS, T. STEIN, K.D. ENTIAN. Entianin, a novel subtilinlike lantibiotic from Bacillus subtilis subsp. spizizenii DSM 15029 with high antimicrobial activity. Applied and Environmental Microbiology, 77: 5, pp. 16981707 (2011).

20. J. PARISOT, S. CAREY, E. BREUKINK, W.C. CHAN, A. NARBAD, B. BONEV. Molecular mechanism of target recognition by subtilin, a class I lanthionine antibiotic. Antimicrobial Agents and Chemotherapy, 52, pp. 612-618 (2008).

21. D. KRUSZEWSKA, H.G. SAHL, G. BIERBAUM, U. PAG, S.O. HYNES, A. LJUNGH. Mersacidin eradicates methicillin-resistant Staphylococcus aureus (MRSA) in a mouse rhinitis model. Journal of Antimicrobial Chemotherapy, 54, pp. 648-653 (2004).

22. J.Y.F. DUBOIS, T.R.H. M. KOUWEN, A.K.C. SCHURICH, C.R. REIS, H.T. ENSING, E.N. TRIP, J.C. ZWEERS, J.M. van DIJL. Immunity to the bacteriocin sublancin 168 is determined by the SunI (YolF) protein of Bacillus subtilis. Antimicrobial Agents and Chemotherapy, 53: 2, pp. 651-661 (2009).

23. Z. HE, D. KISLA, L. ZHANG, C. YUAN, K.B.G. CHURCH, A.E. YOUSEF. Isolation and identification of a Paenibacillus polymyxa strain that coproduces a novel lantibiotic and polymyxin. Applied and Environmental Microbiology, 73, pp. 168-178 (2007).

24. D. LANDMAN, C. GEORGESCU, D.A. MARTIN, J. QUALE. Polymyxins Revisited. Clinical Microbiology Reviews, 21: 3, pp. 449-465 (2008).

25. A.A. ARIAS, M. ONGENA, B. DEVREESE, M. TERRAK, B. JORIS, P. FICKERS. Characterization of Amylolysin, a Novel Lantibiotic from Bacillus amyloliquefaciens GA1. Plos One, 8: 12, pp. 1-10, (2013).

26. A.L. McClERREN, L.E. COOPER, C. QUAN, P.M. THOMAS, N.L. KELLEHER, W.A. Van Der DONK. Discovery and in vitro biosynthesis of haloduracin, a two-component lantibiotic. Proceedings of the National Academy of Sciences, 103: 46, pp. 17243-17248 (2006).

27. J. DISCHINGER, M. JOSTEN, C. SZEKAT, H.G. SAHL, G. BIERBAUM. Production of the novel two-peptide lantibiotic lichenicidin by Bacillus licheniformis DSM 13. Plos One, 4: 8 (2009). 
28. M. BEGLEY, P.D. COTTER, C. HILL, R.P. ROSS. Identification of a novel two-peptide lantibiotic, lichenicidin, following rational genome mining for LanM proteins. Applied and Environmental Microbiology, 75, pp. 5451-5460 (2009).

29. C.E. SHELBURNE, F.Y. AN, D.E. LOPATIN, V. DHOLPE, A. RAMAMOORTHY, M.S. LANTZ. The spectrum of antimicrobial activity of the bacteriocin subtilosin A. Journal of Antimicrobial Chemotherapy, 59, pp. 297-300 (2007).

30. C. LE MARREC, B. HYRONIMUS, P. BRESSOLLIER, B. VERNEUIL, M.C. URDACI. Biochemical and genetic characterization of coagulin, a new antilisterial bacteriocin in the pediocin family of bacteriocins, produced by Bacillus coagulans I4. Applied and Environmental Microbiology, 66, pp. 5213-5220 (2000).

31. J.W. JIN, F. MABOOD, A. SOULEIMANOV, X. ZHOU, S. JAOUA, F. KAMOUN, DONALD L. SMITH. Stability and antibacterial activity of bacteriocins produced by Bacillus thuringiensis and Bacillus thuringiensis ssp. Kurstaki. Journal of Molecular Microbiology and Biotechnology, 18:11, pp. 1836-1840 (2008).

32. S. SEBEI, T. ZENDO, A. BOUDABOUS, J. NAKAYAMA, K. SONOMOTO. Characterization, $\mathrm{N}$-terminal sequencing and classification of cerein MRX1, a novel bacteriocin purified from a newly isolated bacterium: Bacillus cereus MRX1. Journal of Applied Microbiology, 103, pp. 1621-1631 (2007).

33. J. WANG, L. ZHANG, K. TENG, S. SUN, Z. SUN, J. ZHONG. Cerecidins, Novel Lantibiotics from Bacillus cereus with Potent Antimicrobial Activity. Applied and Environmental Microbiology, 80: 8, pp. 2633-2643, (2014).

34. L. ZHANG, K. TENG, J. WANG, Z. ZHANG, J. ZHANG, S. SUN, L. LI, X. YANG, J. ZHONG. CerR, a Single-Domain Regulatory Protein of the LuxR Family, Promotes Cerecidin Production and Immunity in Bacillus cereus. Applied and Environmental Microbiology, 84: 5, pp. 1-14 (2018).

35. D. BIZANI, A.P.M. DOMINGUEZ, A. BRANDELLI. Purification and partial chemical characterization of the antimicrobial peptide cerein 8A. Letters in Applied Microbiology, 41, pp. 269-273 (2005).

36. T. STEIN. Bacillus subtilis antibiotics: structures, syntheses and specific functions. Molecular Microbiology, 56: 4, pp. 845-857 (2005).

37. E.A. ABADA, H.H. EL-HENDAWY, M.E. OSMAN, M.A. HAFEZ. Antimicrobial activity of Bacillus circulans isolated from rhizosphere of Medicago sativa. Life Science Journal, 11:8, pp. 711-719 (2014).

38. M. ALAJLANI, A. SHIEKH, S. HASNAIN, A. BRANTNER. Purification of Bioactive Lipopeptides Produced by Bacillus subtilis Strain BIA. Chromatographia, 79: 21, pp. 1527-1532 (2016).

39. C.R. HARWOOD, J.M. MOUILLON, S. POHL, J. ARNAU. Secondary metabolite production and the safety of industrially important members of the
Bacillus subtilis group. FEMS Microbiology Reviews, 42, pp. 721-738 (2018).

40. Y. TOURE, M. ONGENA, P. JACQUES, A. GUIRO, P. THONART. Role of lipopeptides produced by Bacillus subtilis GA1 in the reduction of grey mould disease caused by Botrytis cinerea on apple, Journal of Applied Microbiology, 96:5, pp. 1151-1160 (2004).

41. M.H.M. ISA, M.A.H.F. SHANNAQ, N. MOHAMED, A.R. HASSAN, N.K.N. AL-SHORGANI, A.A. HAMID. Antibacterial Activity of Surfactin Produced by Bacillus subtilis MSH1. Transactions on Science and Technology, 4: 3, pp. $402-407$ (2017).

42. Q. GOAFU, Z. FAYIN, D. PENG, Y. XIUFEN, Q. DEWEN, Y. ZINIU. Lipopeptide induces apoptosis in fungal cells by a mitochondria-dependent pathway. Peptides, 31:11, pp. 1978-1986 (2010).

43. M. ONGENA, P. JACQUES, Y. TOURE. Involvement of fengycin-type lipopeptides in the multifaceted biocontrol potential of Bacillus subtilis. Applied Microbiology and Biotechnology, 69, pp. 29-38 (2005).

44. T.G. PHISTER, D.J. O'SULLIVAN, L.L. MCKAY. Identification of bacilysin, chlorotetaine and iturin A produced by Bacillus sp strain CS93 isolated from pozol, a Mexican fermented maize dough. Applied and Environmental Microbiology, 70, pp. 631-634 (2004).

45. M. BERDITSCH, M. TRAPP, S. AFONIN, C. WEBER, J. MISIEWICZ, J. TURKSON, A.S. ULRICH. Antimicrobial peptide gramicidin $\mathrm{S}$ is accumulated in granules of producer cells for storage of bacterial phosphagens. Scientific Reports, 7:44324 (2017).

46. J.W. LIOU, Y.J. HUNG, C.H. YANG, Y.C. CHEN. The antimicrobial activity of gramicidin $\mathrm{A}$ is associated with hydroxyl radical formation, Plos One, vol. 10, no. 1, pp. 1-15 (2015).

47. M.A. MARQUES, D.M. CITRON, C. WANG. Development of Tyrocidine A Analogues with Improved Antibacterial Activity. Bioorganic \& Medicinal Chemistry, 15: 21, pp. 6667-6677 (2007).

48. E.A. FELNAGLE, A.D. BERTI, E.E. JACKSON, Y.A. CHAN, A.M. PODEVELS, M.D. MCMAHON, M.G. THOMAS. Nonribosomal Peptide Synthetases Involved in the Production of Medically Relevant Natural Products. Molecular Pharmaceutics, 5: 2, pp. 191-211 (2008).

49. M. WENZEL, M. RAUTENBACH, J.A. VOSLOO, T. SIERSMA, C.H.M. AISENBREY, E. ZAITSEVA, W.E. LAUBSCHER, W. VAN RENSBURG, J.C. BEHRENDS, B. BECHINGER, L.W. HAMOEN. The Multifaceted Antibacterial Mechanisms of the Pioneering Peptide Antibiotics Tyrocidine and Gramicidin S. American Society for Microbiology, 9: 5, pp.1-20 (2018).

50. O.A. SICUIA, F. CONSTANTINESCU, C.P. CORNEA. Biodiversity of Bacillus subtilis group and beneficial traits of Bacillus species useful in plant protection. Romanian Biotechnological Letters, 20: 5, pp. 1073710750 (2015). 
51. E.C. AZEVEDO. Bacitracin production by a new strain of Bacillus subtilis. Extraction, purification and characterization. Applied Biochemistry and Biotechnology, 42, pp. 1-7 (1993).

52. A. AMIN, M.A. KHAN, M. EHSANULLAH, U. HAROON, S.M.F. AZAM, A. HAMEED. Production of peptide antibiotics by Bacillus sp. GU 057 indigenously isolated from saline soil. Brazilian Journal of Microbiology, 43: 4, pp. 1340-1346 (2012).

53. A.A.H.S. AL-JANABI. Identification of Bacitracin Produced by Local Isolate of Bacillus licheniformis. African Journal of Biotechnology, 5: 18, pp. 16001601 (2006).

54. I.V. PINCHUK, P. BRESSOLLIER, I.B. SOROKULOVA, B. VERNEUIL, M.C. URDACI. Amicoumacin antibiotic production and genetic diversity of Bacillus subtilis strains isolated from different habitats. Res Microbiol., 153: 5, pp. 269-76 (2002).

55. S. LIU, X. HAN, Z. JIANG, G. WU, X. HU, X. YOU, J. JIANG, Y. ZHENG, C. SUN. Hetiamacin B-D, new members of amicoumacin group antibiotics isolated from Bacillus subtilis PJS. The Journal of Antibiotics (Tokyo), 69: 10, pp. 769-772 (2016).

56. M. ROMERO-TABAREZ, R. JANSEN, M. SYLLA, H. LUNSDORF, S. HAUBLER, D.A. SANTOSA, K.N. TIMMIS, G. MOLINARI. 7-O-Malonyl Macrolactin A, a New Macrolactin Antibiotic from Bacillus subtilis Active against Methicillin-Resistant Staphylococcus aureus, Vancomycin-Resistant Enterococci and a Small-Colony Variant of Burkholderia cepacia. Antimicrobial Agents and Chemotherapy, 50: 5, pp. 1701-1709 (2006).

57. L.B. ZIMMERMAN, C.D. SCHWARTZ, R.L. MONAGHAN, B.A. PELAK, B. WEISSBERGER, E.C. GILFILLAN, S. MOCHALES, S. HERNANDEZ, S.A. CURRIE, E. TEJERA. Difficidin and Oxydifficidin: Novel Broad Spectrum Antibacterial Antibiotics Produced by Bacillus Subtilis. I. Production, taxonomy, and antibacterial activity. The Journal of Antibiotics, vol. XL, no. 12, pp. 1677-1681 (1987).

58. S.A. BORISOVA, B.T. CIRCELLO, J.K. ZHANG, W. A. VAN DER DONK, W.W. METCALF. Biosynthesis of rhizocticins, antifungal phosphonate oligopeptides produced by Bacillus subtilis ATCC6633. Chemistry and Biology, 17: 1 (2010).

59. L.S. SANTHI, P. TALLURI V.S.S.L, S.Y. NAGENDRA, R.E. KRISHNA. Bioactive Compounds from Marine Sponge Associates: Antibiotics from Bacillus sp., Natural Products Chemistry \& Research, 5: 4, pp. 1-5 (2017).

60. X.L. LU, Q.Z. XU, Y.H. SHEN, L. XIAO-YU. Macrolactin $S$, a novel macrolactin antibiotic from marine Bacillus sp., Natural Product Research, 22: 4, pp. 342-347 (2008).

61. K. NAGAI, K. KAMIGIRI, N. ARAO, K. SUZUMURA. YM-266183 and YM-266184, Novel Thiopeptide Antibiotics Produced by Bacillus cereus Isolated from a Marine Sponge. Part 1. Taxonomy,
Fermentation, Isolation, Physico-Chemical Properties and Biological Properties. The Journal of Antibiotics, 56: 2, pp. 123-128 (2003).

62. A. AMIN, M.A. KHAN, M. EHSANULLAH, A. HAMEED, U. HAROON, S.M.F. AZAM. Production of peptide antibiotics by Bacillus Sp. Gu 057 indigenously isolated from saline soil. Brazilian Journal of Microbiology, 43: 4, pp. 1340-1346 (2012).

63. Z. NASfi, H. BUSCH, S. KEHRAUS, L. LINARESOTOYA, G.M. KÖNIG, T.F. SCHÄBERLE, R. BACHOUAL. Soil bacteria isolated from Tunisian arid areas show promising antimicrobial activities against gram-negative. Frontiers in Microbiology, 9, pp. 1-13 (2018).

64. F. PEYPOUX, J. BONMATIN, J. WALLACH. Recent trends in the biochemistry of surfactin. Applied Microbiology and Biotechnology, vol. 51, pp. 553-563 (1999).

65. J.C. OSCÁRIZ, I. LASA, A.G. PISABARRO. Detection and characterization of cerein 7 , a new bacteriocin produced by Bacillus cereus with a broad spectrum of activity. FEMS Microbiology Letters, 178: 2, pp. 337-341 (1999).

66. N. TAMEHIRO, Y. OKAMOTO-HOSOYA, S. OKAMOTO, M. UBUKATA, M. HAMADA, H. NAGANAWA, K. OCHI. Bacilysocin, a Novel Phospholipid Antibiotic Produced by Bacillus subtilis 168. Antimicrobial Agents and Chemotherapy, 46: 2, pp. $315-320$ (2002).

67. N.S. SHALIGRAM, R.S. SINGHAL. "Surfactin A Review on Biosynthesis, Fermentation, Purification and Applications. Food Technology and Biotechnology, 48: 2, pp. 119-134 (2010).

68. Q. GONG, C. ZHANG, F. LU, H. ZHAO, X. BIE, Z. LU. Identification of bacillomycin $\mathrm{D}$ from Bacillus subtilis fmbJ and its inhibition effects against Aspergillus flavus. Food Control, vol. 36, pp. 8-14 (2014)

69. S. WU, S. JIA, D. SUN, M. CHEN, X. CHEN, J. ZHONG, L. HUAN. Purification and Characterization of Two Novel Antimicrobial Peptides Subpeptin JM4-A and Subpeptin JM4-B Produced by Bacillus subtilis JM4. Current Microbiology, vol. 51, pp. 292-296 (2005)

70. R.W. PHELA, M. BARRET, P.D. COTTER, P.M. O'CONNOR, R. CHEN, J.P. MORRISSEY, A. DOBSON, F. O'GARA, T.M. BARBOSA. Subtilomycin: A New Lantibiotic from Bacillus subtilis Strain MMA7 Isolated from the Marine Sponge Haliclona simulans. Marine Drugs. vol. 11, pp. 1878-1898 (2013).

71. P.K. DAS, S. DAS, D. SAHOO, J. DALEI, V.M. RAO, S. NAYAK, S. PALO. Comparative Evaluation of Purification Methods for Production of Polypeptide Antibiotics - "Polymyxin B" and "Cerexin A" from Bacillus Species. PharmaTutor, 2:8, pp. 188-200 (2014) 